\title{
Serum levels of brain-derived neurotrophic factor and thiobarbituric acid reactive substances in chronically medicated schizophrenic patients: a positive correlation Niveis séricos do fator neurotrófico derivado do cérebro e dos produtos de reação com o ácido tiobarbitúrico em pacientes com esquizofrenia cronicamente medicados: correlação positiva
}

\author{
Clarissa Severino Gama, ${ }^{1,2,3,4}$ Michael Berk, ${ }^{3,5,6}$ Ana Cristina Andreazza, , \\ Flávio Kapczinski, ${ }^{1,2,7}$ Paulo Belmonte-de-Abreu ${ }^{1,2,4}$
}

Abstract

Objective: The neurotrophins, antioxidant enzymes and oxidative markers have reciprocal interactions. This report verified in chronically stable medicated schizophrenic patients whether there are correlations between the serum levels of superoxide dismutase, a key enzyme in the antioxidant defense, thiobarbituric acid reactive substances, a direct index of lipid peroxidation, and brain-derived neurotrophic factor, the most widely distributed neurotrophin. Method: Sixty DSM-IV schizophrenic patients were included (43 males, 17 females). Mean age was $34.7 \pm 10.8$ years, mean age at first episode was $19.8 \pm 7.9$ years, and mean illness duration was $14.9 \pm 8.5$ years. Each subject had a blood sample collected for the determination of serum levels of brain-derived neurotrophic factor, thiobarbituric acid reactive substances and superoxide dismutase. Results: Brain-derived neurotrophic factor levels showed a positive correlation with thiobarbituric acid reactive substances levels $(r=0.333, p=0.009)$. Brain-derived neurotrophic factor levels were not correlated with superoxide dismutase levels $(r=-0.181$, $p=0.166)$, and superoxide dismutase levels were not correlated with thiobarbituric acid reactive substances levels $(r=0.141, p=0.284)$. Conclusions: The positive correlation between brain-derived neurotrophic factor and thiobarbituric acid reactive substances suggests the need of further investigation on intracellular interactions of neurotrophins, antioxidant enzymes and oxidative markers. In addition, this opens a venue for investigation on treatments for the prevention of neurotoxicity along the course of schizophrenia.

Descriptors: Schizophrenia; Brain-derived neurotrophic factor; Superoxide dismutase; Thiobarbituric acid reactive substances; Nerve growth factors

Resumo

Objetivo: As neurotrofinas, enzimas antioxidantes e marcadores de oxidação têm interações. Este estudo verificou se existem correlações entre os níveis séricos de superóxido-dismutase, uma enzima chave na defesa antioxidante, os produtos de reação com o ácido tiobarbitúrico, um indicador direto de peroxidação lipídica, e o fator neurotrófico derivado do cérebro, a neurotrofina mais amplamente distribuída. Método: Sessenta pacientes portadores de Esquizofrenia pelo DSM-IV foram incluídos (43 homens, 17 mulheres), com idade média de 34,7 \pm 10,8 anos, idade média no primeiro episódio de 19,8 \pm 7,9 anos, e tempo médio de duração da doença de 14,9 \pm 8,5 anos. Foi coletado sangue de cada sujeito para a determinação dos níveis séricos de fator neurotrófico derivado do cérebro, superóxido-dismutase e ácido tiobarbitúrico. Resultados: Os níveis de fator neurotrófico derivado do cérebro se correlacionaram positivamente aos de ácido tiobarbitúrico $(r=0,333, p=$ 0 ,009) e não mostraram correlação com os de superóxido-dismutase $(r=-0,181, p=0,166)$. Este último também não se correlacionou aos níveis de ácido tiobarbitúrico $(r=0,141, p=0,284)$. Conclusões: A correlação positiva entre fator neurotrófico derivado do cérebro e ácido tiobarbitúrico direciona para investigações na interação intracelular entre neurotrofinas, enzimas antioxidantes e marcadores de oxidação, além de abrir perspectives para pesquisa em tratamentos para a prevenção da neurotoxicidade ao longo do curso da esquizofrenia.

Descritores: Esquizofrenia; Fator neurotrófico derivado do encélafo; Superóxido dismutase; Substâncias reativas com ácido tiobarbitúrico; Fatores de crescimento neural

\footnotetext{
1 Molecular Psychiatry Laboratory, Research Center, Hospital de Clínicas de Porto Alegre (HCPA), Porto Alegre (RS), Brazil

2 Graduate Program in Medicine: Psychiatry, Universidade Federal do Rio Grande do Sul (UFRGS), Porto Alegre (RS), Brazil

3 Department of Clinical and Biomedical Sciences, Barwon Health, University of Melbourne, Geelong (VIC), Australia

4 Schizophrenia Program, Hospital de Clínicas de Porto Alegre (HCPA), Porto Alegre (RS), Brazil

5 Orygen Research Centre, Parkville, Australia

6 Mental Health Research Institute, Parkville, Australia

7 Bipolar Disorders Program, Hospital de Clínicas de Porto Alegre (HCPA), Porto Alegre (RS), Brazil
}

Schizophrenia Program, Hospital de Clínicas de Porto Alegre (HCPA), Porto Alegre (RS), Brazil.

Correspondence

Clarissa Severino Gama

Laboratório de Psiquiatria Molecular, Centro de Pesquisas

Hospital de Clínicas de Porto Alegre

Rua Ramiro Barcelos, 2350 


\section{Introduction}

The pathophysiology of schizophrenia (SZ) could be the result of deregulation of synaptic plasticity with downstream alterations of neurotrophins. ${ }^{1}$ Oxygen free radicals may play an important role in the pathophysiology of SZ. ${ }^{2}$ Increased neuronal oxidative stress levels produce deleterious effects on signal transduction, structural plasticity and cellular resilience, mostly by inducing lipid peroxidation in membranes and direct damage in proteins and genes. ${ }^{3}$

Thiobarbituric acid reactive substances (TBARS) are a direct index of cell lipid peroxidation. ${ }^{2}$ Oxidative stress and alterations in antioxidant enzymes have long been described in the pathophysiology of SZ.2,4 Lipid peroxidation, assessed by TBARS levels, has been shown to be increased in chronically medicated patients with $\mathrm{SZ},{ }^{5}$ and in those presenting marked psychotic symptoms. ${ }^{6}$

High levels of superoxide dismutase (SOD), a key enzyme in the endogenous antioxidant defense pathways, are reported in patients with SZ. ${ }^{5}$ We found no differences in SOD activity in chronically medicated patients with SZ presenting three different clinical course patterns (partial remission of psychotic symptoms, marked psychotic symptoms, deterioration). ${ }^{6}$

Brain-derived neurotrophic factor (BDNF) is the most widely distributed neurotrophin in the central nervous system (CNS), and performs many biological functions such as neural survival, differentiation, and plasticity. ${ }^{7}$ Increased BDNF levels in individuals with chronic SZ on long-term treatment with antipsychotics are described. ${ }^{8}$

Neurotrophins, antioxidant enzymes and oxidative markers have complex and reciprocal interactions. Both in vitro and in animal models, ${ }^{9}$ the presence of reactive oxygen species and related oxidative damage acts as a potent messenger stimulus to the production of defenses. These include free radical scavenger enzymes such as SOD and a compensatory increase in BDNF levels. ${ }^{10,11}$ It is however unclear if this in vitro and in animal model processes operate clinically.

The aim of this report is to verify whether there are correlations between BDNF, SOD and TBARS, and between SOD and TBARS in chronically stable medicated patients with SZ.

\section{Method}

\section{Subjects}

This study protocol was approved by the Ethical Committee (06-346) of Hospital de Clínicas de Porto Alegre-RS, Brazil (HCPA). In accordance with the Declaration of Helsinki, all subjects were advised about the procedure and signed the informed consent prior to participation in the study. The cohort consisted of 43 males and 17 females, had a mean age of $34.7 \pm 10.8$ years and a mean age at first episode of $19.8 \pm$ 7.9 years, with a mean illness duration of $14.9 \pm 8.5$ years. Twenty-seven were taking clozapine, 14 were taking typical antipsychotics and 19 other atypical antipsychotics. The mean antipsychotic daily dose use, in milligrams of chlorpromazine equivalents, was $475.36 \pm 246.10$.

Patients were on chronic medication, and had a Clinical Global Impression (CGI) ${ }^{12}$ score $\leq 3$ assessed by a trained psychiatrist. None of them had a psychiatric hospitalization for the last 5 years. This group of patients had to fulfill Diagnostic and Statistical Manual of Mental Disorders, fourth Edition (DSM-IV) criteria for SZ. ${ }^{13}$

Each subject had $5 \mathrm{ml}$ blood samples collected by venipuncture without anticoagulants, and serum was obtained by centrifugation at $3,000 \mathrm{xg}$ for 5 minutes and kept frozen at $-70^{\circ} \mathrm{C}$ for up to 6 months, until the assay.

\section{Determination of serum levels of BDNF}

BDNF serum levels were measured with sandwich-ELISA, using a commercial kit according to the manufacturer's instructions (Chemicon, USA). Briefly, microtiter plates (96-well flat-bottom) were coated for $24 \mathrm{~h}$ with the samples diluted $1: 2$ in sample diluents and standard curve ranged from 7.8 to $500 \mathrm{pg}$ of BDNF. Plates were then washed four times with wash buffer, monoclonal anti-BDNF rabbit antibody added (diluted 1:1000 with sample diluents), and incubated for 3 hours at room temperature. After washing, a second incubation with anti-rabbit antibody peroxidase conjugated (diluted $1: 1000$ ) for $1 \mathrm{~h}$ at room temperature was carried out. After addition of streptavidin-enzyme, substrate and stop solution, the amount of BDNF was determined (absorbance set at $450 \mathrm{~nm}$ ). The standard curve demonstrates a direct relationship between optical density (OD) and BDNF concentration. Total protein was measured by Lowry's method using bovine serum albumin as a standard.

\section{SOD activity}

SOD activity was determined spectrophotometrically in serum samples by measuring the inhibition of the rate of autocatalytic adrenochrome formation at $480 \mathrm{~nm}$, in a reaction medium containing $1 \mathrm{mmol} / \mathrm{l}$ adrenaline $(\mathrm{pH} 2)$ and $50 \mathrm{mmol} / \mathrm{l}$ glycine $(\mathrm{pH}$ 10.2). This reaction was conduced at a constant temperature (30 ${ }^{\circ} \mathrm{C}$ ) for 3 minutes. The enzymatic activity was expressed as SOD units per $g$ of protein. One unit is defined as the amount of enzyme that inhibits the rate of adrenochrome formation by $50 \% .{ }^{14}$

\section{TBARS}

Serum levels of malondialdehyde (MDA), a product of lipid peroxidation, were measured by the TBARS method described by Wills. ${ }^{15}$ Peroxidation was measured as the production of MDA, which in combination with TBARS forms a pink chromogen, i.e. a compound whose absorbance at $530 \mathrm{~nm}$ was measured. MDA results were expressed as $\mathrm{nmol} / \mathrm{ml}$.

\section{Statistical analysis}

Analysis was performed using Statistical Product and Service Solutions 15.0 Version (SPSS). Relationships between variables were assessed with Spearman-rank correlation coefficient. Kruskal-Wallis test was performed to analyze the variance between groups. Data were presented as mean \pm Standard Deviation, and p-values $<0.05$ were considered significant.

\section{Results}

Mean BDNF serum levels, in pg/ug protein, were $1.19 \pm$ 1.00 , mean serum levels of SOD activity, in USOD/g, were 8.52 \pm 4.64 , and mean serum levels of TBARS, in $\mathrm{nmol} / \mathrm{ml}$, were $4.86 \pm 1.35$.

BDNF serum levels showed a positive correlation with TBARS serum levels $(r=0.333, p=0.009)$ (Figure 1$)$. BDNF levels were not correlated with SOD levels $(r=-0.181, p=0.166)$, and SOD levels failed to show correlation with TBARS levels $(r=0.141, p=0.284)$.

Any of the sample's characteristics were correlated with BDNF levels: age $(r=0.070, p=0.593)$, age at first episode $(r=-0.021$, $p=0.874)$, illness duration $(r=0.004, p=0.977)$ and mean antipsychotic daily dose $(r=0.138, p=0.295)$; with SOD levels: age $(r=-0.041, p=0.755)$, age at first episode $(r=0.142$, $p=0.281)$, illness duration $(r=-0.074, p=0.574)$ and mean antipsychotic daily dose $(r=0.127, p=0.333)$; and with TBARS levels: age $(r=0.169,0.196)$, age at first episode $(r=-0.023$, 


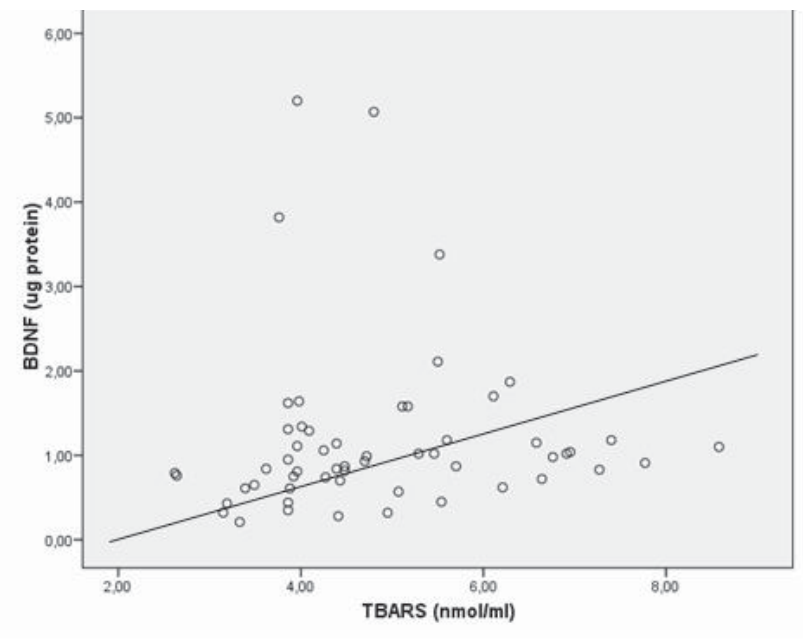

Figure 1 - Positive correlation between serum Brain-Derived Neurotrophic Factor (BDNF) and Thiobarbituric Acid Reactive Substances (TBARS) levels in 60 patients with schizophrenia $(r=0.333 ; p=0.009$ - Spearman-rank correlation coefficient)

$p=0.861)$, illness duration ( $r=0.115, p=0.383$ ) and mean antipsychotic daily dose $(r=-0.040, p=0.760)$.

There were no differences in SOD activity $(p=0.520)$, BDNF $(p=0.809)$ and TBARS $(p=0.389)$ levels between patients taking clozapine, typical or atypical antipsychotics.

\section{Discussion}

As far as we are aware, this is the first report of positive correlation between BDNF and TBARS in chronically medicated patients with SZ.

Altered neuronal functioning occurs in SZ, mediated by changes in membrane fluidity or by alterations in membrane receptors, ${ }^{4}$ which can cause impairment of neurotransmitter uptake and release, and even cell death. Significant neurodegenerative processes occur in SZ, and the high levels of BDNF compared to controls found by us in the same SZ sample ${ }^{8}$ may result either as a reaction to the damage, or the chronic phase of the disorder may be a period of reduced metabolic aggression to the brain. However, the positive correlation between BDNF and TBARS found by us in vivo, and the other two reports of this correlation in vitro and in animal model, ${ }^{10,11}$ help to support the evidence of high levels of BDNF as a compensation mechanism for the oxidative damage and consequent metabolic stress; at least, in this cohort of chronically medicated SZ patients.

A negative correlation between BDNF and TBARS was found in a bipolar disorder (BD) cohort during manic episodes. ${ }^{16}$ The finding of this study together with the previous finding of high BDNF levels in $\mathrm{SZ}^{8}$ seem to give additional support for the hypothesis of differential patterns of damage among SZ and BD, with an early degenerative component in SZ preceding illness onset and an episode-dependent pattern of deterioration in BD. Once BDNF needs CNS tissue to show its action, the inverse pattern of correlation between BDNF and TBARS in BD and SZ seems to corroborate the early CNS damage hypothesis in SZ.

Either SOD or TBARS levels are higher in SZ patients compared to controls. ${ }^{4}$ Among patients with SZ, TBARS levels are higher in those with marked psychotic symptoms, but not SOD levels. ${ }^{6}$ Thus, the positive correlation between BDNF and TBARS may be a reaction to the increased TBARS levels or a compensatory mechanism to the presence of oxidative stress in the brain due to impairment in antioxidant enzymes, like SOD, to buffer the free oxygen species.

\section{Conclusions}

The positive correlation between BDNF and TBARS suggests the need of further investigation with regards to intracellular interactions of neurotrophins, antioxidant enzymes and oxidative markers. In addition, this opens a venue for investigation on the role of neurotrophins, and antioxidant treatments, in the prevention of neurotoxicity in the course of SZ.

\section{Acknowledgements}

This study was supported by grants from FIPE-HCPA (\#06346). Clarissa Severino Gama is funded by CNPq (PDE \#200310/2007-0), Brazil; and Endeavour Awards Programme (\#539/2008), Australia.

\section{Disclosures}

\begin{tabular}{|c|c|c|c|c|c|c|c|}
\hline $\begin{array}{l}\text { Writting group } \\
\text { member }\end{array}$ & Employment & Research grant $^{1}$ & $\begin{array}{l}\text { Other research grant or } \\
\text { medical continuous } \\
\text { education }\end{array}$ & $\begin{array}{l}\text { Spekear's } \\
\text { honoraria }\end{array}$ & $\begin{array}{c}\text { Ownership } \\
\text { interest }\end{array}$ & $\begin{array}{l}\text { Consultant/ } \\
\text { Advisory } \\
\text { board }\end{array}$ & Other $^{3}$ \\
\hline $\begin{array}{l}\text { Clarissa Severino } \\
\text { Gama }\end{array}$ & HCPA & $\begin{array}{l}\text { CNPq }^{* *} \\
\text { Endeavour** } \\
\text { HCPA-FIPE* }\end{array}$ & --- & $\begin{array}{c}\text { Astra- } \\
\text { Zeneca* } \\
\text { Lundbeck* }^{*}\end{array}$ & --- & $\begin{array}{l}-- \\
\end{array}$ & --- \\
\hline Michael Berk & $\begin{array}{l}\text { University of } \\
\text { Melbourne }\end{array}$ & Stanley Foundation** & --- & Lilly** & --- & --- & --- \\
\hline $\begin{array}{l}\text { Ana Cristina } \\
\text { Andreazza }\end{array}$ & HCPA & --- & --- & --- & --- & --- & --- \\
\hline Flavio Kapczinski & UFRGS & $\begin{array}{c}\text { CNPq }^{* *} \\
\text { FIPE-HCPA* } \\
\text { Stanley Foundation** } \\
\text { NARSAD** }\end{array}$ & $\begin{array}{c}\text { Lilly* }^{*} \\
\text { Astra-Zeneca* } \\
\text { Janssen* }\end{array}$ & $\begin{array}{c}\text { Eli Lilly* } \\
\text { Astra-Zeneca* }\end{array}$ & $\begin{array}{l}-- \\
\end{array}$ & Servier* & --- \\
\hline $\begin{array}{l}\text { Paulo Belmonte- } \\
\text { de-Abreu }\end{array}$ & UFRGS & $\begin{array}{l}\text { HCPA-FIPE* } \\
\text { CAPES }\end{array}$ & --- & --- & --- & --- & --- \\
\hline
\end{tabular}

* Modest

** Significant

*** Significant. Amounts given to the author's institution or to a colleague for research in which the author has participation, not directly to the author.

Note: HCPA = Hospital de Clínicas de Porto Alegre; UFRGS = Universidade Federal do Rio Grande do Sul; CNPq = Conselho Nacional de Desenvolvimento Cientifico e Tecnológico; FIPE/HCPA = Fundo de Incentivo à Pesquisa do Hospital de Clínicas de Porto Alegre; NASARD = National Alliance for Research on Schizophrenia and Depression; CAPES = Coordenação de Aperfeiçoamento de Pessoal de Nível Superior.

For more information, see Instructions for authors. 


\section{References}

1. Gratacos M, Gonzalez JR, Mercader JM, de Cid R, Urretavizcaya M, Estivill X. Brain-derived neurotrophic factor Val66Met and psychiatric disorders: meta-analysis of case-control studies confirm association to substance-related disorders, eating disorders, and schizophrenia. Biol Psychiatry. 2007;61(7):911-22.

2. Reddy RD, Yao JK. Free radical pathology in schizophrenia: a review. Prostaglandins Leukot Essent Fatty Acids. 1996;55(1-2):33-43.

3. Andreazza AC, Kauer-Sant'anna M, Frey BN, Bond DJ, Kapczinski F, Young LT, Yatham LN. Oxidative stress markers in bipolar disorder: a meta-analysis. J Affect Disord. 2008;111(2-3):135-44.

4. Grignon S, Chianetta JM. Assessment of malondialdehyde levels in schizophrenia: a meta-analysis and some methodological considerations. Prog Neuropsychopharmacol Biol Psychiatry. 2007;31(2):365-9.

5. Gama CS, Salvador M, Andreazza AC, Kapczinski F, Silva Belmontede-Abreu P. Elevated serum superoxide dismutase and thiobarbituric acid reactive substances in schizophrenia: a study of patients treated with haloperidol or clozapine. Prog Neuropsychopharmacol Biol Psychiatry. 2006;30(3):512-5.

6. Gama CS, Salvador M, Andreazza AC, Lobato MI, Berk M, Kapczinski F, Belmonte-de-Abreu PS. Elevated serum thiobarbituric acid reactive substances in clinically symptomatic schizophrenic males. Neurosci Lett. 2008;433(3):270-3.

7. Qian L, Zhao J, Shi Y, Zhao X, Feng G, Xu F, Zhu S, He L. Brain-derived neurotrophic factor and risk of schizophrenia: an association study and meta-analysis. Biochem Biophys Res Commun. 2007;353(3): 738-43.

8. Gama CS, Andreazza AC, Kunz M, Berk M, Belmonte-de-Abreu PS, Kapczinski F. Serum levels of brain-derived neurotrophic factor in patients with schizophrenia and bipolar disorder. Neurosci Lett. 2007;420(1):45-8.

9. Salgado JV, Hetem LA, Sandner G. Experimental models of schizophrenia - a review. Rev Bras Psiquiatr. 2006;28(2):135-41.

10. Gabaizadeh R, Staecker H, Liu W, Van De Water TR. BDNF protection of auditory neurons from cisplatin involves changes in intracellular levels of both reactive oxygen species and glutathione. Brain Res $\mathrm{Mol}$ Res. 1997;50(1-2):71-8.

11. Radak Z, Toldy A, Szabo Z, Siamilis S, Nyakas C, Silye G, Jakus J, Goto S. The effects of training and detraining on memory, neurotrophins and oxidative stress markers in rat brain. Neurochem Int. 2006;49(4):387-92.

12. Guy W. ECDEU assessment manual for psychopharmacology US Department of Health, Education, and Welfare publication (ADM) 76-338. Rockville, MD: National Institute of Mental Health; 1976. p. 218-22.

13. Azevedo MH, Soares MJ, Coelho I, Dourado A, Valente J, Macedo A, Pato M, Pato C. Using consensus OPCRIT diagnoses. An efficient procedure for best-estimate lifetime diagnoses. $\mathrm{Br} J$ Psychiatry. 1999; 175:154-7

14. Mirsa HP, Fridovich I. The role of superoxide anion in the autoxidation of epinephrine and a simple assay for superoxide dismutase. J Biol Chem. 1972;217(10):3170-5.

15. Wills ED. Mechanism of lipid peroxide formation in animal tissues. Biochem J. 1966;99(3):667-76.

16. Kapczinski F, Frey BN, Andreazza AC, Kauer- Sant'Anna M, Cunha $A B M$, Post RM. Increased oxidative stress as a mechanism for decreased BDNF levels in acute manic episodes. Rev Bras Psiquiatr. 2008;30(3):243-5. 